\title{
Integrated Nutrient Management in Rice-Wheat Cropping System: An Evidence on Sustainability in the Indian Subcontinent through Meta-Analysis
}

\author{
Sheetal Sharma ${ }^{1, *}$, Rajeev Padbhushan ${ }^{2}$ and Upendra Kumar ${ }^{3}(\mathbb{D}$ \\ 1 International Rice Research Institute-India Office, 1st Floor, CG Block, NASC Complex, DPS Marg, Pusa, \\ New Delhi 110012, India \\ 2 International Rice Research Institute-Odisha Office, Plot no. 340/C, School St., Saheed Nagar, Bhubaneswar, \\ Odisha 751007, India; r.padbhushan@irri.org \\ 3 National Rice Research Institute (NRRI), Bidyadharpur, Cuttack, Odisha 753006, India; \\ ukumarmb@gmail.com \\ * Correspondence: sheetal.sharma@irri.org
}

Received: 21 January 2019; Accepted: 2 February 2019; Published: 7 February 2019

\begin{abstract}
Over years of intensive cultivation and imbalanced fertilizer use, the soils of the Indian subcontinent have become deficient in several nutrients and are impoverished in organic matter. Recently, this region has started emphasizing a shift from inorganic to organic farming to manage soil health. However, owing to the steadily increasing demands for food by the overgrowing populations of this region, a complete shift to an organic farming system is not possible. The rice-wheat cropping system (RWCS) is in crisis because of falling or static yields. The nations of this region have already recognized this problem and have modified farming systems toward integrated nutrient management (INM) practices. The INM concept aims to design farming systems to ensure sustainability by improving soil health, while securing food for the population by improving crop productivity. Therefore, this paper was synthesized to quantify the impact and role of INM in improving crop productivity and sustainability of the RWCS in the context of the Indian subcontinent through meta-analysis using 338 paired data during the period of 1989-2016. The meta-analysis of the whole data for rice and wheat showed a positive increase in the grain yield of both crops with the use of INM over inorganic fertilizers only (IORA), organic fertilizers only (ORA), and control (no fertilizers; CO) treatments. The increase in grain yield was significant at $p<0.05$ for rice in INM over ORA and CO treatments. For wheat, the increase in grain yield was significant at $p<0.05$ in INM over IORA, ORA, and CO treatments. The yield differences in the INM treatment over IORA were 0.05 and $0.13 \mathrm{Mg}$ $\mathrm{ha}^{-1}$, respectively, in rice and wheat crops. The percent yield increases in INM treatment over IORA, ORA, and CO treatments were 2.52, 29.2, and 90.9, respectively, in loamy soil and 0.60, 24.9, and 93.7, respectively, in clayey soil. The net returns increased by $121 \%$ (INM vs. CO) in rice, and $9.34 \%$ (INM vs. IORA) and $127 \%$ (INM vs. CO) in wheat crop. Use of integrated nutrient management had a positive effect on soil properties as compared to other nutrient management options. Overall, the yield gain and maintenance of soil health due to INM practices over other nutrient management practices in RWCS can be a viable nutrient management option in the Indian subcontinent.
\end{abstract}

Keywords: integrated nutrient management; rice; wheat; yield; net returns; soil health; sustainability

\section{Introduction}

Rice (Oryza sativa L.) and wheat (Triticum aestivum L.) crops are major staple foods, contributing a key portion of digestible energy and protein in human intake and occupying a premium position among all food communities [1-3]. The rice-wheat cropping system (RWCS) is one of the most 
prominent cropping systems prevailing on the Indian subcontinent and is considered to be of utmost importance for food security and livelihood [4-7]. The RWCS occupies about 13.5 million hectares spread over the Indian subcontinent, namely, India, Pakistan, Nepal, Bangladesh, Sri Lanka, and Bhutan, and accounting for one-fourth to one-third of total food grain production [8,9]. This cropping system covers about one-third of the total rice cultivation and two-fifths of the total wheat cultivation in the Indian subcontinent. Currently, more than nine-tenths of global rice is produced and consumed in these nations [10].

Natural resources, primarily agricultural lands, are limited globally. To meet the food demand of the ever-increasing population, agriculture must produce more food grains from limited cultivable land [11]. The crop productivity of the region is low and oscillating from $0.5 \mathrm{t} \mathrm{ha}^{-1}$ to $2.5 \mathrm{t} \mathrm{ha} \mathrm{a}^{-1}$, with a mean of $1.5 \mathrm{tha}^{-1}$. The increasing population and food consumption and the decline in existing arable land and other units of supply are placing exceptional pressure on the present farming system to meet the growing food demand. To counteract this problem and obtain higher yields, crop growers are shifting to fertilizer-responsive high-yielding varieties and avoiding the overuse of inputs such as synthetic fertilizers. The soils under the RWCS are now showing signs of fatigue and are no longer showing increased production with an increase in fertilizer use [12]. Even with the use of the recommended rate of fertilizer in the RWCS, a negative balance of primary nutrients has been recorded. To obtain food security in these nations, crop yields must rise considerably while ecological effects must contract significantly [13]. Figures 1 and 2 represent the trends and ratio of rice-wheat production and fertilizer consumption in the Indian subcontinent. These show that, from 1961 to 2016 , rice-wheat production increased by four times, whereas fertilizer consumption increased by 67 times, which clearly indicates the slower increase in rice-wheat production even though fertilizer consumption was increasing at an exponential rate. Hence, innovative interventions are required to optimize fertilizer use and sustain the rice-wheat production system in this region.

Intensive cropping systems with continuous imbalanced use of synthetic fertilizers to feed fertilizer-responsive varieties have caused losses in soil organic carbon (SOC) [14] and soil health [15-17], often leading to unsustainability of crop production systems. The use of organic sources of nutrients in agriculture is rapidly gaining favor but, owing to the problems related to the lack of availability of a good quality and quantity of organic materials, the system may not be sufficient to achieve and sustain the production of cereal crops in the amounts required for food security [17].

Integrated nutrient management (INM) or integrated nutrient supply (INS) help to achieve efficient use of synthetic fertilizers integrated with organic sources of nutrients [18]. INM is developed with an understanding of the interactions among crops, soils, and climate, which advocates the integration of inorganic and organic sources of nutrients. This approach is based on the maintenance of plant nutrition supply to attain a certain level of crop production by enhancing the benefits from all potential sources of plant nutrition in a cohesive manner, applicable to each cropping pattern and farming scenario [19]. The inclusion of organic manures regulates the uptake of nutrients, positively affecting production, improving soil quality (physical, chemical, and biological), and producing a synergistic effect on crops [20]. INM integrates traditional and recent practices of nutrient management into an environmentally sound and cost-effective ideal farming system that uses remunerations from all probable sources of nutrition (organic, inorganic, and biological) in a careful, effective, and combined way [21,22]. It optimizes the balance between input sources and outputs with the goal of coordinating the nutritional demand of the crop and its discharge in its surroundings (Figure 3). 


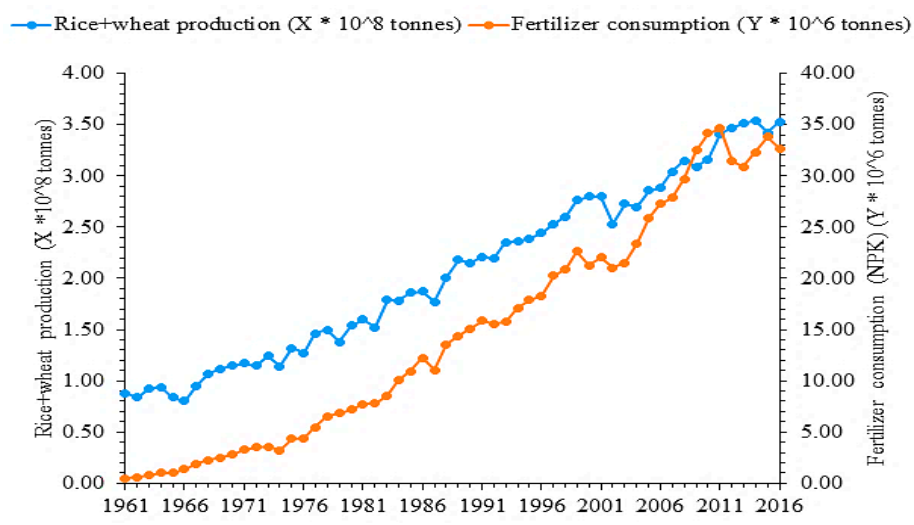

Figure 1. Trends of rice + wheat production and fertilizer consumption during the period 1961-2016 on the Indian subcontinent, Reproduced with permission from FAO (http://faostat.fao.org/).

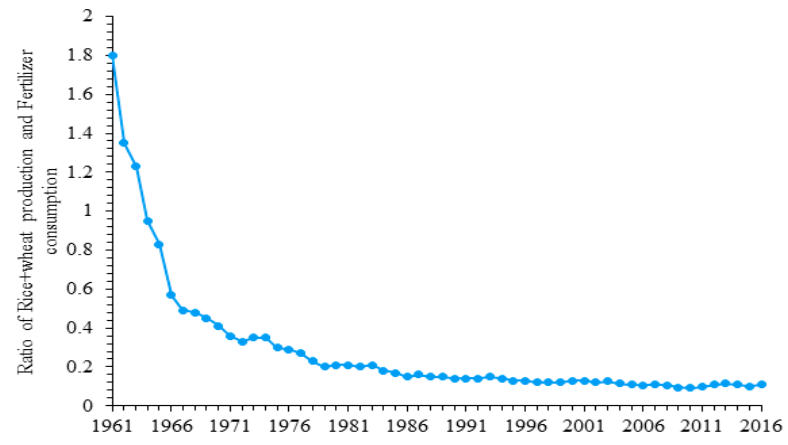

Figure 2. Ratio of rice + wheat production and fertilizer consumption during the period 1961-2016 on the Indian subcontinent, FAO (http:/ / faostat.fao.org/).

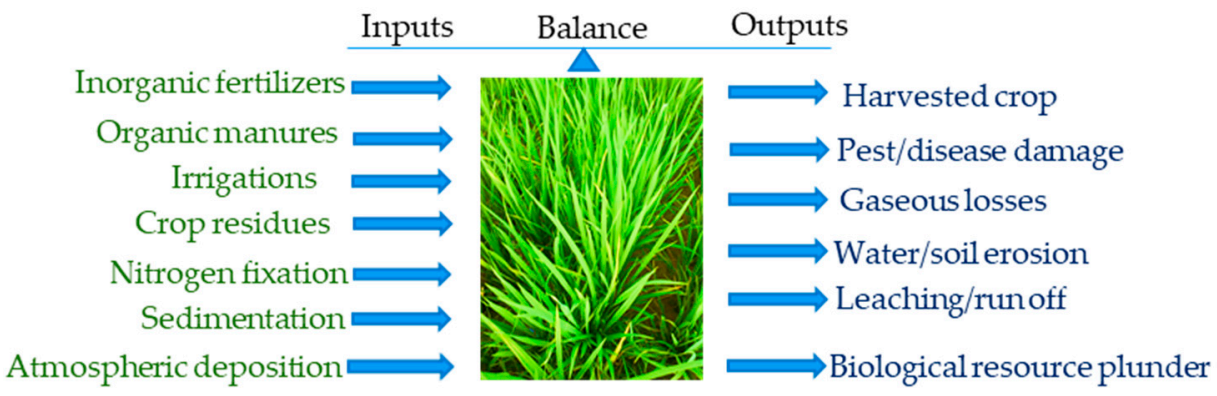

INM method based on inputs and outputs:

- Matching the quantity with demand of the crop

- Synchronizing in terms of time with crop growth

Figure 3. Mean of nutrients for inputs and outputs, and the principles of integrated nutrient management systems [22,23].

The importance of INM practices has been mentioned in several researches in the Indian subcontinent. The INM concept is now being broadened to make it more context-specific for local environmental conditions, increasing mechanization (due to the serious labor shortage as a result of migration), the increasing popularity of conservation agriculture, upcoming rain-harvesting technologies, and the increasing focus on recycling of available organic nutrient flows [22]. The incorporation of these new interventions in an INM system has developed new dimensions in the INM system and thus makes these practices synthesized for the region. An innovative approach such as INM can harness natural resources appropriately, bring about food security, and improve the livelihood of the people in the region [24]. The provision of appropriate policies, such as an incentive to adopt INM, will motivate small-holder farmers to adopt INM. Legislation on or the taxing of nutrient 
inputs should be enforced to minimize the use of inorganic fertilizers and encourage the integration of organic fertilizers for nutrient management.

The RWCS is a fertilizer-responsive cropping system. However, the imbalanced and excessive application of inorganic fertilizers is detrimental to the soil ecosystem and ultimately affects crop yield. Organic farming, a traditional production system relying on the use of only organic sources of nutrients, is supposed to be the production system that causes minimal damage to the ecosystem. However, the organic farming system has become a fundamental topic for discussion in recent times, with concerns about whether it can produce enough food to feed the ever-growing population of the Indian subcontinent $[25,26]$. On the Indian subcontinent, around a half century ago, the population was controlled and technology was not advanced. Organic manures were the only sources of nutrients. Currently, with the increase in the availability of new sources of nutrients, there is a need to recognize them and develop integrated options to increase production which are both ecologically viable and linked to economic growth.

Several researchers showed the impact of INM over other nutrient management options, such as the use of organic fertilizers only (ORA), the use of inorganic fertilizers only (IORA), or the use of no fertilizers as a control (CO), through their studies of the RWCS and undoubtedly, INM has emerged as a viable alternative nutrient management option in the RWCS for the Indian subcontinent. Researchers have compared yield and other performance parameters of nutrient management options, but an attempt to synthesize information in the RWCS, particularly in the Indian subcontinent region, is critically lacking. Such kinds of synthesis can help to prioritize research and development issues, including precise technology targeting, and articulate policy and institutional measures to facilitate large-scale adoption of nutrient management options.

Therefore, the present paper aimed to perform a comprehensive meta-analysis to understand the impacts of INM on crop performance in the RWCS of the Indian subcontinent during the period of 1989-2016. This study also outlines the sustainability of INM, noting that sole dependence on inorganic fertilizers or organic farming could not serve the purpose of the food security of the ever-growing populations in these countries. The role of INM is discussed for resolving those complications and as one of the promising strategies for addressing the current challenges of crop output and sustainability of the RWCS in these nations.

\section{Materials and Methods}

\subsection{Data Collection}

Literatures were reviewed for the period from 1989 to 2016 related to the on-station field experiments using integrated organic and inorganic nutrient sources with an aim of finding the effect of INM on crop productivity, net returns, and different soil parameters in the Indian subcontinent. After general review, they were critically analyzed, and data pertaining to INM along with other treatments (control (no fertilizer applied), organic fertilizer alone, and inorganic fertilizer alone) were selected. The treatment with $100 \%$ NPK (Nitrogen-Phosphorous-Potassium) application was selected as inorganic alone. Meta-analysis was conducted for the selected data (338 paired datasets) from several researchers to show the impact of INM over the other nutrient management options.

Only studies that met the following criteria were included:

1. Rice and wheat as study crops.

2. Nutrient management options include INM-integration of organic and inorganic sources (option 1); ORA — use of organic source of nutrient application only (option 2); or IORA—full dose of inorganic fertilizer application that mean recommended dose fertilizer application (option 3).

3. CO: Control treatments where no fertilizers were added.

4. Two soil textures: Loamy (moderately coarse to medium fine) and clayey (moderately fine to fine). 


\subsection{Crop and Soil Performance Parameters and Economic Analysis Used for Meta-Analysis Study}

The following performance parameters were considered in the analysis: (a) Grain yield $\left(\mathrm{Mg} \mathrm{ha}^{-1}\right)$, (b) soil parameters: Bulk density (BD; $\mathrm{Mg} \mathrm{m}^{-3}$ ), soil $\mathrm{pH}$ (soil water ratio:1:2), soil organic carbon (SOC; $\%$ ), total nitrogen ( $\mathrm{TN} ; \mathrm{kg} \mathrm{ha}^{-1}$ ), available phosphorus (Av. P; $\mathrm{kg} \mathrm{ha}^{-1}$ ), available potassium (Av. K; $\mathrm{kg} \mathrm{ha}^{-1}$ ), and soil microbial biomass carbon (SMBC; $\mathrm{mg} \mathrm{kg}^{-1}$ ), and (c) net returns (NR; $\$ \mathrm{ha}^{-1}$ ) (Net returns data from the study points was converted from INR ha ${ }^{-1}$ to US\$ ha ${ }^{-1}$ for meta-analysis).

\subsection{Meta-Analysis}

All the variables were subjected to meta-analysis separately for rice and wheat and for soil texture. Meta-analysis has attracted considerable attention recently as a powerful statistical tool to analyze the response of treatments (i.e., nutrient management options vs. $\mathrm{CO}$ ) from diverse individual studies to evolve to a general global trend or pattern. The meta-analysis was performed by using Meta Win 2.1 in two stages [27], in which effect size was calculated using the formula:

$$
\text { Effect size }=\frac{M(\mathrm{NM})}{M(\mathrm{INM})}
$$

where $M(\mathrm{NM})$ is the mean of response variables (Grain yield, NR, soil parameters) of options 2, 3, and $\mathrm{CO}$, and $M$ (INM) is the mean of these variables of option 1 . Since most researchers did not report the variance of the means of response variables, the effect sizes were weighted based on the number of replicates $(N)$ as follows:

$$
\text { Weight }=\frac{N(\mathrm{NM}) \times N(\mathrm{INM})}{N(\mathrm{NM})+N(\mathrm{INM})}
$$

where $N(\mathrm{NM})$ and $N(\mathrm{INM})$ represent the number of replications for each of the nutrient management options, in an individual study. In cases where more than one observation was included in an option, the number of observations from that research was divided by the weights. All the results are discussed as change with INM over other nutrient management options and CO. Unless stated otherwise, differences were considered significant only when $p$ values were $<0.05$. The meta-analyzed value has been presented either in graph or in table to clearly show the effect of INM over the other nutrient management options.

\section{Results}

\subsection{Impact of INM on Rice and Wheat Yield and Net Returns}

The meta-analysis of the data for rice and wheat showed positive increases in the grain yield of both crops with the use of INM over IORA, ORA, and CO treatments (Figure 4). The increase in grain yield was significant at $p<0.05$ for rice in INM over ORA and CO treatments. The data show that some of the study points in INM over IORA for rice crop were negative, but the effect was non-significant. The increases in wheat grain yield were significant in INM over IORA, ORA, and CO treatments. The respective percent yield increases in INM treatment over CO, ORA, and IORA treatments were 86.5, 28.1, and 1.2 in rice crop, and 104.6, 39.2, and 4.5 in wheat crop. On average, the yield differences in the INM treatment over IORA were 0.05 and $0.13 \mathrm{Mg} \mathrm{ha}^{-1}$ in rice and wheat crop, respectively.

The data showed a significant increase in grain yield with INM over IORA, ORA, and CO treatments under loamy soils (Figure 4). Under clayey soils, there was an increase in grain yield in INM over IORA, ORA, and CO treatments, but the effect was non-significant for IORA and ORA treatments (Figure 4). The percent yield increases in INM treatment over CO, ORA and IORA treatments were $90.9,29.2$, and 2.52, respectively, in loamy soil, and 93.7, 24.9, and 0.60, respectively, in clayey soil. The yield gains calculated through meta-analysis of various studies for INM treatment over other nutrient management options suggest that INM can be a viable nutrient management option for reversing the yield plateauing in both rice wheat cropping systems of the Indian subcontinent. 


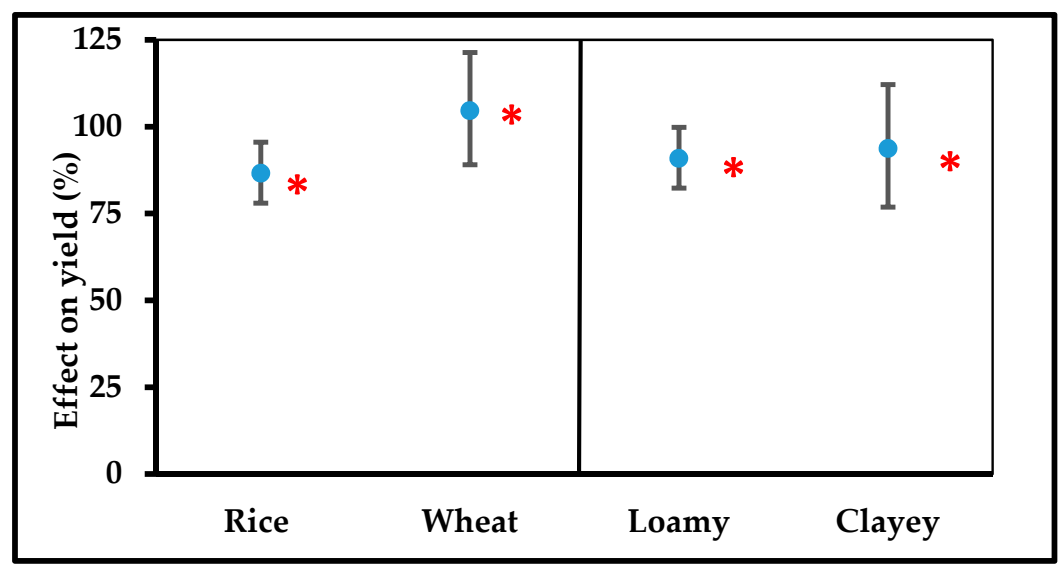

(a) Integrated nutrient management vs. Control

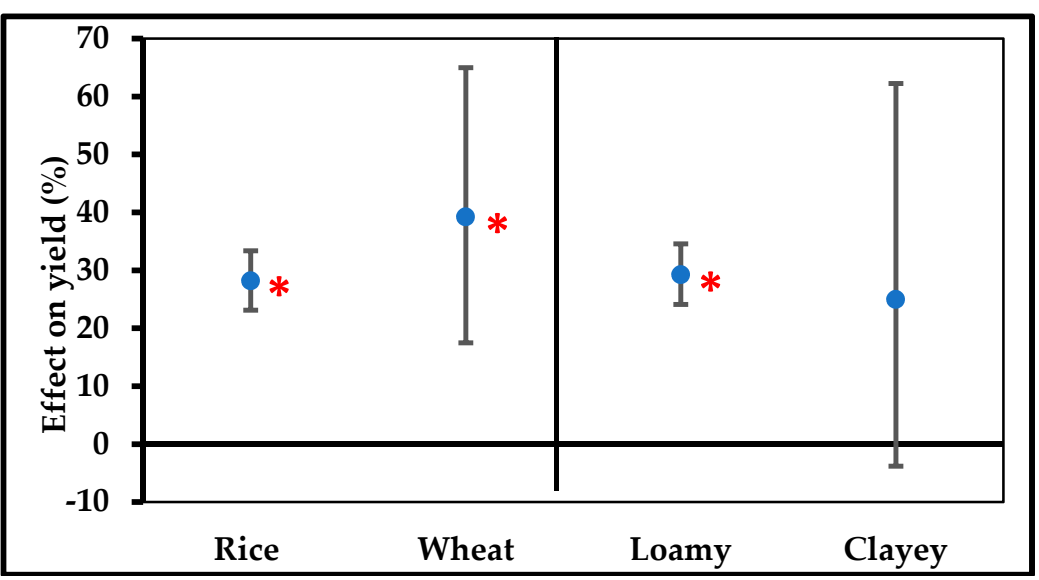

(b) Integrated nutrient management vs. Organic alone

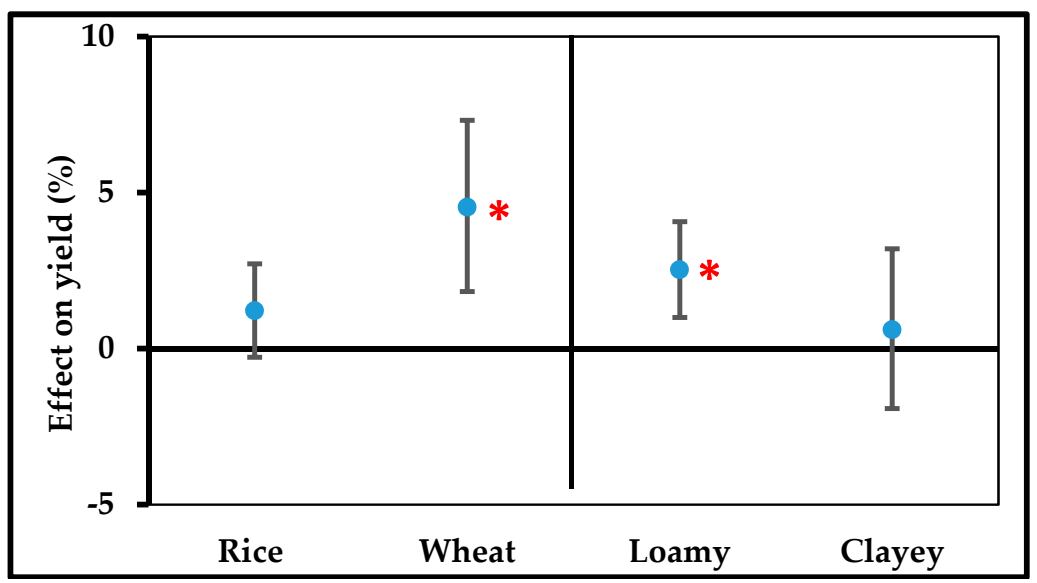

(c) Integrated nutrient management vs. Inorganic alone

Figure 4. Effect of integrated nutrient management on grain yield vis-a vis control (a), organic alone (b), and inorganic alone (c), separated for rice and wheat crops and for soil texture (loamy and clayey). (Note: Error bars in meta-analysis indicate 95\% confidence intervals (CI), where effect of yield was considered significant if $95 \%$ CI does not cover zero. ${ }^{*}$ Indicates significant percent yield at $p<0.05$ ).

Table 1 represents meta-analysis of the data, showing the effects of nutrient management practices on net returns in rice and wheat crops. The data for rice showed a significant positive increase in net returns with INM over the CO. The effect was significantly positive for INM over CO and IORA in wheat crop. The increases were 121 percent in NM vs. CO for rice, 9.34 and 127 per cent in INM vs. 
IORA and INM vs. CO, respectively, for wheat crop. The net returns increased by $0.13 \%$ in INM over ORA in wheat, but this was non-significant. Net returns decreased by $2.34 \%$ in INM vs. IORA and $0.27 \%$ in INM vs. ORA for rice crop, but these were non-significant. The negative effect in these cases was due to increased cost of cultivations in some of the studies.

Table 1. Influence on net returns in rice and wheat with integrated nutrient management over inorganic alone, organic alone, and control treatments in percent.

\begin{tabular}{ccc}
\hline \multirow{2}{*}{ Nutrient Management Practices } & \multicolumn{2}{c}{ Crops } \\
\cline { 2 - 3 } & Rice & Wheat \\
\hline INM vs. IORA & $-2.93(-9.48$ to 3.93$)$ & $9.34(4.28$ to 15.07$) *$ \\
INM vs. ORA & $-0.27(-3.78$ to 3.37$)$ & $0.13(-3.85$ to 4.27$)$ \\
INM vs. CO & $121(101$ to 142$) *$ & $127(97$ to 156$) *$ \\
\hline
\end{tabular}

Mean values are given with $95 \% \mathrm{CI}$ in parentheses. In bracket the values represent the ranges of percent net return for compared nutrient management practices. ${ }^{*}$ Indicates percent net returns significant at $p<0.05$. Where INM stands for integrated nutrient management, IORA for inorganic alone, ORA for organic alone, and CO for control (No fertilizer applied). CI used for confidence interval.

\subsection{Effect of INM on Soil Characteristics}

Crop- and texture-wise meta-analysis for the effect of INM compared to IORA, ORA, and CO treatments on various soil properties is presented in Table 2. The effect was non-significant for bulk density (BD) for both crops and soil textures. The BD increased by $0.53 \%$ (INM vs. IORA) and $1.15 \%$ (INM vs. CO) in rice crop. In wheat crop, the BD decreased by $0.98 \%$ (INM vs. IORA) and $0.55 \%$ (INM vs. CO). In loamy soil, BD decreased by $0.94 \%$ in INM vs. IORA and increased by $0.19 \%$ in INM vs. CO. In clayey soil, BD increased by $1.85 \%$ in INM vs. IORA and $1.38 \%$ in NM vs. CO.

The data for soil $\mathrm{pH}$ showed a positive effect of INM with an increase of $1.15 \%$ over $\mathrm{CO}$ in rice. However, the effect was negative by $0.55 \%$ in wheat crop for INM vs. CO. In clayey soil, $\mathrm{pH}$ increased by $1.85 \%$ in INM vs. IORA. The effect on soil $\mathrm{pH}$ was significantly negative for INM vs. CO, decreasing by $0.98 \%$ in wheat crop, and in INM vs. IORA by $0.94 \%$ in loamy soil (Table 2$)$. The effects for all other comparisons were non-significant.

Meta-analysis of SOC showed a significant positive effect for all comparisons with sufficient data points, both crop-wise and texture-wise (Table 2). The SOC increased by $23.2 \%$ in INM vs. IORA and by $34.95 \%$ in INM vs. CO for rice. The increases were $16.2 \%$ in INM vs. IORA and $52.09 \%$ in INM vs. CO for wheat. In loamy soil, the increases were $26.5 \%$ in INM vs. IORA, and $51.21 \%$ in INM vs. CO. In clayey soils, the increases were $12.29 \%$ in INM vs. IORA and $23.4 \%$ in INM. There was no sufficient data for meta-analysis for INM vs. ORA.

For all the compared treatments, the TN, Av. P, Av. K, and SMBC showed significant positive effects for rice and wheat crops, indicating that INM treatment improved these soil properties over lone application of organic and inorganic fertilizers and CO (Table 2). Texture-wise, there was a significantly positive effect of INM over other nutrient management NM practices and CO for Av. P, Av. K, and SMBC. 
Table 2. Effect of integrated nutrient management on soil properties with respect to inorganic alone, organic alone, and control treatments for rice and wheat crops and as influenced by soil texture (loamy and clayey), in percent.

\begin{tabular}{|c|c|c|c|c|c|}
\hline \multirow{2}{*}{ Soil Parameters } & \multirow{2}{*}{ Nutrient Management Practices } & \multicolumn{2}{|c|}{ Crops } & \multicolumn{2}{|c|}{ Texture Groups } \\
\hline & & Rice & Wheat & Loamy & Clayey \\
\hline \multirow{3}{*}{$\mathrm{BD}$} & INM vs. IORA & $0.53(-1.33$ to 2.44$)$ & $-0.98(-3.83$ to 1.96$)$ & $-0.94(-2.87$ to 1.04$)$ & $1.85(-0.79$ to 4.55$)$ \\
\hline & INM vs. ORA & \# & \# & \# & \# \\
\hline & INM vs. CO & $1.15(-0.74$ to 3.07$)$ & $-0.55(-3.42$ to 2.42$)$ & $0.19(-1.77$ to 2.19$)$ & $1.38(-1.24$ to 4.06$)$ \\
\hline \multirow{3}{*}{ Soil pH } & INM vs. IORA & $0.53(-0.13$ to 1.33$)$ & $-0.98(-1.24$ to -0.68$) *$ & $-0.94(-1.28$ to -0.58$) *$ & $1.85(0.84$ to 3.02$) *$ \\
\hline & INM vs. ORA & $-0.27(-3.78$ to 3.37$)$ & $0.13(-3.85$ to 4.27$)$ & $-0.07(-2.68$ to 2.60$)$ & $-0.31(-45.34$ to 81.83$)$ \\
\hline & INM vs. CO & $1.15(0.24$ to 2.18$) *$ & $-0.55(-0.99$ to -0.14$) *$ & $0.19(-1.77$ to 2.19$)$ & $1.38(-1.24$ to 4.06$)$ \\
\hline \multirow{3}{*}{ SOC } & INM vs. IORA & $23.20(18.55$ to 27.48$) *$ & $16.20(9.94$ to 21.95$) *$ & $26.50(21.05$ to 31.19$) *$ & $12.29(9.74$ to 14.88$) *$ \\
\hline & INM vs. ORA & $\#$ & \# & $\#$ & $\#$ \\
\hline & INM vs. CO & $34.95(28.08$ to 41.92$) *$ & $52.09(41.79$ to 66.53$) *$ & $51.21(43.43$ to 59.79$) *$ & $23.40(17.95$ to 29.38$) *$ \\
\hline \multirow{3}{*}{$\mathrm{TN}$} & INM vs. IORA & $49.86(42.99$ to 57.07$) *$ & $71.26(60.11 \text { to } 83.16)^{*}$ & \# & $\#$ \\
\hline & INM vs. ORA & 29.01 (24.93 to 33.22$)$ * & $29.16(25.08$ to 33.38$)$ * & \# & \# \\
\hline & INM vs. CO & $28.49(25.46$ to 31.59$) *$ & $29.16(24.82$ to 33.66$)$ * & $\#$ & $\#$ \\
\hline \multirow{3}{*}{ Av. P } & INM vs. IORA & $15.94(12.24$ to 19.76$) *$ & $4.88(-0.45$ to 10.47$)$ & 17.15 (13.18 to 21.26$) *$ & $5.30(0.58$ to 10.23$) *$ \\
\hline & INM vs. ORA & $12.68(3.97$ to 22.12$) *$ & $11.28(1.42$ to 22.09$)$ * & 12.49 (5.95 to 19.45$)$ * & $7.14(-69.39$ to 275.05$)$ \\
\hline & INM vs. CO & $37.18(21.93$ to 54.34$) *$ & $53.54(31.93$ to 78.68$)$ * & $54.64(38.89$ to 72.17$)$ * & $21.35(3.40 \text { to } 42.40)^{*}$ \\
\hline \multirow{3}{*}{ Av. K } & INM vs. IORA & $15.33(11.20$ to 20.21$)$ * & $1.69(-7.04$ to 9.84$)$ & $13.36(7.06$ to 19.97$) *$ & $7.52(4.75$ to 10.69$) *$ \\
\hline & INM vs. ORA & $9.10(7.36$ to 10.82$) *$ & $9.46(7.97$ to 11.02$) *$ & $9.74(8.68$ to 10.83$)$ * & $3.48(2.84$ to 4.12$)$ * \\
\hline & INM vs. CO & $30.23(24.68$ to 36.12$) *$ & $18.32(14.50$ to 22.52$) *$ & $26.29(21.85$ to 31.48$) *$ & $23.97(18.07$ to 30.12$) *$ \\
\hline \multirow{3}{*}{ SMBC } & INM vs. IORA & $55.91(44.09$ to 68.67$) *$ & $32.92(23.50$ to 43.05$)$ * & $56.19(46.29$ to 66.76$) *$ & $28.44(19.12$ to 38.49$)$ * \\
\hline & INM vs. ORA & \# & $\#$ & \# & \# \\
\hline & INM vs. CO & $97.90(70.98$ to 129.03$) *$ & $111.11(95.15$ to 128.35$)$ * & 134.03 (116.41 to 153.07$)$ * & $99.23(79.98$ to 103.16$)$ * \\
\hline
\end{tabular}

\# Data not sufficient for meta-analysis. Mean values are given with $95 \% \mathrm{CI}$ in parentheses. In brackets the values represent the ranges of percent net return for compared nutrient for control (No fertilizer applied), BD means bulk density, SOC means soil organic carbon, TN means total nitrogen, Av. P means available phosphorus, Av. K means available potassium, SMBC means soil microbial biomass carbon and CI used for confidence interval. 


\section{Discussion}

The above results in this article for the period 1989-2016, obtained through meta-analysis, emphasize the importance of INM practices in the Indian subcontinent. The crop-wise and texture-wise analyses show positive effects of INM treatment over IORA and ORA on grain yield. The increase in yield due to the use of INM treatment puts forth that the integration of organic sources of nutrients with inorganic fertilizers could be a viable alternative nutrient management option in RWCS in the Indian subcontinent. Although the yield gains in the INM treatment over the IORA treatment were only $1.2 \%$ in rice and $4.5 \%$ in wheat, considering that the conditions of curtailing the use of inorganic fertilizers prevent the soil quality/health from ill effects of synthetic fertilizers, this would really show the benefits of the use of INM over IORA treatment. From this study, it is clear that the use of the ORA did not serve the purpose of enhancing crop productivity in both crops and hence, complete shifting towards organic farming cannot be a feasible option as far as human food security is concerned. Similar findings were also pointed out by different researchers of the Indian subcontinent. In Bangladesh, researchers reported that integrated use of Sesbania (dhaincha) and mung bean residues with inorganic sources of nutrients improved crop yield by $7.6 \%$ and $9.5 \%$, respectively, over inorganic alone in $T$. aman rice [28]. The application of wheat straw or farm yard manure (FYM) along with inorganic fertilizer in the rice field recorded higher grain and straw yields of rice in comparison to the treatments with only inorganic fertilizer [29]. The grain yields of basmati rice and wheat in the RWCS when $50 \%$ of the recommended dose from chemical fertilizers was substituted with green manure (GM) significantly increased crop productivity by $100 \%$ [30]. The incorporation of green gram residues along with inorganic fertilizers resulted in a significant rice yield increase of $13 \%$ over IORA [31]. The highest yield of $4.68 \mathrm{Mg} \mathrm{ha}^{-1}$ in wheat crop was recorded when $50 \% \mathrm{~N}$ (nitrogen) of the recommended dose of fertilizer treatment was replaced with FYM in the rice crop [32].

The yield response to the soil texture group suggests that INM treatment appears to be more suitable in loamy soil in comparison to clayey soil. The reason is that loamy soils have better drainage than clayey soils, and therefore offer adequate aeration. The better performance in these soils is also because of less cracking of soil in the early state, which is critical for the rice crop. Cracking is high in clayey soil, which directly affects the plant. The plant-available water content is also higher in these soils [33].

The data show that the use of INM increased net returns in several studies over other nutrient management options. Although, increases in the cost of cultivation at a few instances resulted in negative values under meta-analysis. For wheat crop, the effect of INM treatment on net returns was positive over the other nutrient management options. In case of rice, INM vs. IORA showed declines in net returns, but the effect was not significant. This may be due to large variations in effects of treatments for net returns. Proper planning and management can decrease the cost of cultivation for INM in the instances with high cost of cultivation and can bring in a positive effect on net returns for RWCS.

The study clearly indicated the positive effect of INM on soil characteristics over other nutrient management options. The increases in SOC, TN, Av. P, Av. K, and SMBC correlated the INM with enhanced soil quality/health. Continuous use of chemical fertilizers alone affects the soil reaction by increasing hydrogen ions $\left(\mathrm{H}^{+}\right)$in the soil during the formation of ammonia. The soil reaction in turn affects the supply of nutrients in the soil. The use of compost with inorganic fertilizers reduced soil $\mathrm{pH}$ significantly over the IORA treatment [34]. The reduction in soil $\mathrm{pH}$ is due to the formation of organic acids by the reactions between compost and the inorganic fertilizers in the presence of microorganisms. The dissolution of salts by formed acids under INM significantly improved the electrical conductivity (EC) of the soil. Thus, the use of INM regulates $\mathrm{pH}$ and EC of the soil due to the presence of organic sources, hence improving nutrient availability in the soil.

The integrated application of organic and inorganic fertilizers for 29 years reduced soil reactions by $0.22 \%$ over the application of inorganic fertilizers alone [32]. In a long-term fertilizer experiment under the RWCS, it was reported that INM reduced BD by $16.6 \%$, whereas the application of IORA 
showed a reduction of $7.3 \%$ compared to the CO treatment [35]. The effects of INM on nutrient dynamics were recorded, and it was concluded that combining FYM with inorganic fertilizers could maintain SOC and available $\mathrm{N}$ and $\mathrm{P}$ at either equal to or greater than the initial soil nutrient levels, thus maintaining soil fertility even under continuous cultivation [36]. Incorporation of rice straw with green manure along with inorganic fertilizers increased Av. P by $12.7 \%$ and Av. K by $14.3 \%$, as compared to treatments in which only inorganic sources of nutrients were applied [37]. Sesbania green-manuring in rice, integrated with inorganic fertilizers, increased the available $\mathrm{N}$ from 5.8 to $22.0 \mathrm{~kg} \mathrm{ha}^{-1}, \mathrm{Av}$. P from 1.4 to $3.8 \mathrm{~kg} \mathrm{ha}^{-1}$, and Av. $\mathrm{K}$ from 2.2 to $17.9 \mathrm{~kg} \mathrm{ha}^{-1}$ in comparison to IORA [38]. The use of INM in the RWCS increased SOC content by $21 \%$ [32] and $45.8 \%[39,40]$ over the application of IORA.

The study [3] analyzed apparent balances of the nutrients N, P, and K in the RWCS for an average of 28 years as influenced by a combination of organic and inorganic sources of nutrients. Apparent $\mathrm{N}$ balance was negative for the $\mathrm{CO}$ and IORA, whereas apparent $\mathrm{N}$ balance was positive for INM ( $50 \%$ recommended dose of fertilizer $+50 \% \mathrm{~N}$ straw). This shows that the nutrient $\mathrm{N}$ was recycled through an organic supplement. Similar positive results for apparent $\mathrm{P}$ balance were observed in the INM treatment over the CO. The positive balance shows more $\mathrm{P}$ accumulation due to an affirmative linear relationship between the available and surplus $\mathrm{P}$. Apparent $\mathrm{K}$ balance was negative for all the treatments (INM, IORA, and CO). INM plays a key role in retaining the balance between demand and supply of nutrients in the soil-plant system. Under the current scenario, sustainable $\mathrm{N}, \mathrm{P}$, and $\mathrm{K}$ management strategies need to be identified for optimal production and nutrient balance. The balances deliver key information about the sustainability of the RWCS and the potential environmental impacts [41,42]. It is worth noting that one-fourth of the $\mathrm{N}$ and four-fifths of the $\mathrm{K}$ removed by the rice and wheat crop remain in the straw and are obtainable after incorporation to the soil. Application of straw residues in the field can thus reduce the recommended dose of chemical fertilizer. At present, it has been assessed that only $33 \%$ to $50 \%$ of the applied $\mathrm{N}$ and P fertilizers are used by crops [43,44]. The efficacy of the applied nutrients might be enhanced by the integrated use of inorganic and organic fertilizers, by increasing the availability of these nutrients to the crops [45]. Declining trends in RWCS productivity and the need for higher inputs have been observed due to the depletion of organic matter in the soil, which causes a disturbance in aggregate stability, soil productivity, and soil quality/health $[46,47]$. Thus, there is a need for partial substitution of inorganic fertilizers by locally available organic sources of nutrients for sustainable production [48-50].

Long-term studies conducted at several sites on the Indian subcontinent indicate that the application of required nutrients only by inorganic fertilizers affects soil health [51]. The application of unwarranted nutrients could lead to a decline in nutrient-use efficiency, making fertilizer application uneconomical and resulting in an adverse effect on the environment [52] and groundwater quality [53], causing health hazards and ill effects on the climate. Therefore, there is a need to enhance the nutrient supply system through INM that brings sustainable changes in the soil-plant system and the environment $[54,55]$.

Soil sequesters atmospheric carbon in the soil, which improves the productivity and quality of the ecosystem [56]. The integrated use of organic manure and inorganic fertilizer is an indispensable component to manage soil in an arable crop production system. The application of INM can enhance plant available nutrients, but the amendments can also affect the soil microbial population. The use of organic manures for managing soil quality/health has been well recognized [57]. Soil biodiversity is the population of microbes that manage or enhance soil health. The microbial population enhances nutrient availability. Soil microbes and the mechanisms to control the activities are important for maintaining the long-term sustainability of farming systems [58], and are key factors in nutrient cycling and soil genesis. The activity and biomass of the microbes play a key role in enhancing soil quality/health [59], as these respond to soil and crop management practices [60]. The bacterial and fungal populations are compared in the INM-treated plot compared to the inorganic-treated plot [61]. The bacterial population increased by approximately $60 \%$, whereas the fungal population almost 
doubled in the INM system in comparison with the IORA. The increase in microbial population is due to the conducive soil environment, formed by the organic addition increasing the magnitude of easily degradable carbonaceous compounds in the INM system supporting nutrition for soil inhabitants. The INM application also improves physical components such as porosity, water-holding capacity, and aggregate stability, and decreases surface crusting and soil bulk density. INM also helps in improving structure, air capacity, and water retention in the soil profile [62].

Thus, the INM system improves soil quality by regulating the soil reaction, building up SOC, improving soil physical properties, and improving nutrient solubility/mobility. By integrating organic and inorganic sources, the added SOC can aid in the sustenance of agriculture for a longer period than inorganic sources alone, especially in the tropical climate of the Indian subcontinent where the temperature remains high and organic matter decomposition is rapid. INM is the key to sustaining our soils for improving productivity and preserving soil quality and environmental sustainability. Because the agricultural production system is a combined shared effect of the soil-water-fertilizer-climate continuum (SWFCC), a sensible and methodical management of this multifaceted system is vital for improving crop productivity on a continual basis. Among the several inputs of the nutrient balance, water and nutrients are the critical inputs that contribute the most to crop yield. The use of these inputs in a better manner and interactive effect with other factors is essential for targeting crop yield potential. Practices to manage soil through tillage can improve the efficiency of these input factors. Sustainable agricultural promotion uses the efficient integration of soil, water, soil organic matter, tillage, and nutrients for achieving yield targets of the RWCS. INM aims to promote sustainable production systems by managing soil quality together with improving crop yield through the balanced integration of organic and inorganic sources [63].

The studies reported improvements in yields, net profit, and soil characteristics in the RWCS with the use of INM, and attributed the increases to improvements in the availability of nutrients, increases in resource-use efficiencies, and increases in resistance to environmental stresses with the use of INM [22,64-68]. Farmers of these nations can be benefited with the use of INM through increased productivity and profitability. This will not only reduce the excessive use of inorganic fertilizers but also improve soil quality/health and ensure food security and environmental sustainability on the Indian subcontinent.

\section{Conclusions}

This review paper emphasized the role and importance of an integrated nutrient management system as a management strategy that can bring sustainability to the rice-wheat cropping system of the Indian subcontinent. The meta-analysis data points of rice and wheat during the period of 1989-2016 revealed that INM treatment over inorganic alone, organic alone, and control treatments was positive on grain yield, both crop-wise as well as texture-wise. The present paper also concludes that net returns through integrated nutrient management treatment were increased by $121 \%$ and $127 \%$ in rice and wheat, respectively, compared to control. Finally, the findings of the present review suggested that INM can be one of the viable nutrient management options in the Indian subcontinent, particularly for the rice-wheat cropping system.

Author Contributions: S.S. provided overall leadership, conceived the conceptual framework and was in charge of overall direction and planning. R.P. did literature search. S.S., R.P. and U.K. wrote the manuscript. All authors discussed the results and contributed to the final manuscript.

Acknowledgments: We are grateful to all the researchers whose contributions have been cited in this paper, which have helped us to prepare this review study.

Conflicts of Interest: The authors declare no conflict of interest. 


\section{Abbreviations}

$\begin{array}{ll}\text { RWCS } & \text { Rice-wheat cropping System } \\ \text { INM } & \text { Integrated nutrient management } \\ \text { SOC } & \text { Soil organic carbon } \\ \text { INS } & \text { Integrated nutrient supply } \\ \text { ORA } & \text { Organic only } \\ \text { IORA } & \text { Inorganic only } \\ \text { CO } & \text { Control (No fertilization) } \\ \text { TN } & \text { Total nitrogen } \\ \text { N } & \text { Nitrogen } \\ \text { Av. P } & \text { Soil available phosphorus } \\ \text { Av. K } & \text { Soil available potassium } \\ \text { ANB } & \text { Apparent nutrient balance } \\ \text { FYM } & \text { Farm yard manure } \\ \text { SWFCC } & \text { Soil-water-fertilizer-climate continuum }\end{array}$

\section{References}

1. Timsina, J.; Connor, D.J. Productivity and management of rice-wheat cropping systems: Issues and challenges. Field Crop. Res. 2001, 69, 93-132. [CrossRef]

2. Singh, R.A.; Singh, J.; Yadav, D.; Singh, H.K.; Singh, J. Integrated nutrient management in rice-wheat cropping system. Int. J. Agric. Sci. 2012, 8, 523-526.

3. Das, A.; Sharma, R.P.; Chattopadhyaya, N.; Rakshit, R. Yield trends and nutrient budgeting under a long-term (28 years) nutrient management in rice-wheat cropping system under subtropical climatic condition. Plant Soil Environ. 2014, 60, 351-357. [CrossRef]

4. Gupta, R.K.; Naresh, R.K.; Hobbs, P.R.; Jiaguo, Z.; Ladha, J.K. Sustainability of post green revolution agriculture: The rice-wheat cropping systems of Indo-Gangetic plains and China. In Improving the Productivity and Sustainability of the Rice-Wheat System: Issues and Impact; Ladha, J.K., Hill, J.E., Duxbury, J.M., Gupta, R.K., Buresh, R.J., Eds.; ASA Special Publication No. 65; American Society Agronomy, Crop Science Society American, Soil Sciien Society American: Madison, WI, USA, 2003; pp. 1-25.

5. Mohanty, S.; Nayak, A.K.; Kumar, A.; Tripathi, R.; Shahid, M.; Bhattacharyya, P.; Raja, R.; Panda, B.B. Carbon and nitrogen mineralization kinetics in soil of rice-rice system under long term application of chemical fertilizers and farmyard manure. Eur. J. Soil Biol. 2013, 58, 113-121. [CrossRef]

6. Kalhapure, A.; Singh, V.P.; Kumar, R.; Pandey, D.S. Tillage and nutrient management in wheat with different plant geometries under rice-wheat cropping system: A review. Basic Res. J. Agric. Sci. Rev. 2015, 4, $296-303$.

7. Zhao, J.T.N.; Lia, J.; Lua, Q.; Fanga, Z.; Huang, Q.; Lia, R.Z.R.; Shen, B.; Shena, Q. Effects of organic-inorganic compound fertilizer with reduced chemical fertilizer application on crop yields, soil biological activity and bacterial community structure in a rice-wheat cropping system. Appl. Soil Ecol. 2016, 99, 1-12. [CrossRef]

8. Abrol, I.P.; Bronson, K.F.; Duxbury, J.M.; Gupta, R.K. Long-term soil fertility experiments in rice-wheat cropping systems. In Long-Term Soil Fertility Experiments with Rice-Wheat Rotations in South Asia; Rice-Wheat Consortium Paper Series No. 1; Abrol, I.P., Ed.; Rice-Wheat Consortium for the Indo-Gangetic Plains: New Delhi, India, 1997; pp. 14-15.

9. Ladha, J.K.; Dawe, D.; Pathak, H.; Padre, A.T.; Yadav, R.L.; Singh, B.; Singh, Y.; Singh, Y.; Singh, P.; Kundu, A.L.; et al. How extensive are yield declines in long-term rice-wheat experiments in Asia? Field Crop. Res. 2003, 81, 159-180. [CrossRef]

10. Dobermann, A.; Cassman, K.G. Precision nutrient management in intensive rice systems: The need for another on-farm revolution. Better Crop. 1996, 10, 20-25.

11. Hobbs, P.R.; Sayre, K.; Gupta, R. The role of conservation agriculture in sustainable agriculture. Philos. Trans. R. Soc. B Biol. Sci. 2008, 363, 543-555. [CrossRef]

12. Benbi, D.K.; Brar, J.S.A. 25-year record of carbon sequestration and soil properties in intensive agriculture. Agron. Sustain. Dev. 2009, 29, 257-265. [CrossRef]

13. Foley, J.A.; Ramankutty, N.; Brauman, K.A.; Cassidy, E.S.; Gerber, J.S.; Johnston, M. Solutions for a cultivated planet. Nature 2011, 478, 337-342. [CrossRef] [PubMed] 
14. Singh, R.P.; Mundra, M.C.; Gupta, S.C.; Agrawal, S.K. Effect of integrated nutrient management on productivity of pearl millet-wheat cropping system. Indian J. Agron. 1999, 44, 250-253.

15. Anwar, M.; Patra, D.D.; Chand, S.; Kumar, A.; Naqvi, A.A.; Khanuja, S.P.S. Effect of organic manures and inorganic fertilizer on growth, herb and oil yield, nutrient accumulation, and oil quality of French basil. Commmun. Soil Sci. Plant Anal. 2005, 36, 1737-1746. [CrossRef]

16. Kumar, U.; Shahid, M.; Tripathi, R.; Mohanty, S.; Kumar, A.; Bhattacharyya, P.; Lal, B.; Gautam, P.; Raja, R.; Panda, B.B.; et al. Variation of functional diversity of soil microbial community in sub-humid tropical rice-rice cropping system under long-term organic and inorganic fertilization. Ecol. Indic. 2017, 73, 536-543. [CrossRef]

17. Kumar, U.; Nayak, A.K.; Shahid, M.; Gupta, V.V.S.R.; Panneerselvam, P.; Mohanty, S.; Kaviraj, M.; Kumar, A.; Chatterjee, D.; Lal, B.; et al. Continuous application of inorganic and organic fertilizers over 47 years in paddy soil alters the bacterial community structure and its influence on rice production. Agric. Ecosyst. Environ. 2018, 262, 65-75. [CrossRef]

18. Mahajan, A.; Bhagat, R.M.; Gupta, R.D. Integrated nutrient management in sustainable rice-wheat cropping system for food security in India. SAARC J. Agric. 2008, 6, 1-13.

19. Mahajan, A.; Sharma, R. Integrated nutrient management (INM) system: Concept, need and future strategy. Agrobios. Newsl. 2005, 4, 29-32.

20. Yadav, D.S.; Kumar, A. Integrated nutrient management in rice-wheat cropping system under eastern Uttar Pradesh. Indian Farm. 2000, 50, 28-30.

21. Janssen, B.H. Integrated nutrient management: The use of organic and mineral fertilizers. In The Role of Plant Nutrients for Sustainable Crop Production in Sub-Saharan Africa; Van Reuler, H., Prins, W.H., Eds.; Ponsen and Looijen: Wageningen, The Netherlands, 1993; pp. 89-105.

22. Wu, W.; Ma, B. Integrated nutrient management (INM) for sustaining crop productivity and reducing environmental impact: A review. Sci. Total Environ. 2015, 512-513, 415-427. [CrossRef]

23. Gruhn, P.; Goletti, F.; Yudelman, M. Integrated Nutrient Management, Soil Fertility and Sustainable Agriculture: Current Issues and Future Challenges; International Food Policy Research Institute: Washington, DC, USA, 2000.

24. Timsina, J. Can organic sources of nutrients increase crop yields to meet global food demand? Agronomy 2018, 8, 214. [CrossRef]

25. Niggli, U.; Fliebbach, A.; Hepperly, P.; Scialabba, N. Low Greenhouse Gas Agriculture: Mitigation and Adaptation Potential of Sustainable Farming Systems; Food and Agriculture Organization of the United Nations: Rome, Italy, 2009.

26. Padbhushan, R.; Rakshit, R.; Das, A.; Sharma, R.P. Effects of various organic amendments on organic carbon pools and water stable aggregates under a scented rice-potato-onion cropping system. Paddy Water Environ. 2016, 14, 481-489. [CrossRef]

27. Rosenberg, M.S.; Adams, D.C.; Gurevitch, J. MetaWin: Statistical Software for Meta-Analysis, Version 2.0; Sinauer Associates: Sunderland, MA, USA, 2000.

28. Zaman, S.K.; Jahiruddin, M.; Panaullah, G.M.; Mian, M.H.; Islam, M.R. Integrated nutrient management for sustainable yield in rice-rice cropping system. In Proceedings of the 17th WCSS, Bangkok, Thailand, 14-21 August 2002.

29. Kumar, M.; Singh, R.P.; Rana, N.S. Effect of organic and inorganic sources of nutrition on productivity of rice. Ind. J. Agron. 2003, 48, 175-177.

30. Bhoite, S.V. Integrated nutrient management in basmati rice (Oryza sativa)-wheat (Triticum aestivum) cropping system. Indian J. Agron. 2005, 50, 98-101.

31. Surekha, K.; Rao, K.V. Direct and residual effects of organic sources on rice productivity and soil quality of vertisols. J. Indian Soc. Soil Sci. 2009, 57, 53-57.

32. Kumari, R.; Kumar, S.; Kumar, R.; Das, A.; Kumari, R.; Choudhary, C.D.; Sharma, R.P. Effect of long-term integrated nutrient management on crop yield, nutrition and soil fertility under rice-wheat system. J. Appl. Nat. Sci. 2017, 9, 1801-1807. [CrossRef]

33. Chakraborty, D.; Ladha, J.K.; Rana, D.S.; Jat, M.L.; Gathala, M.K.; Yadav, S.; Rao, A.N.; Ramesha, M.S.; Raman, A. A global analysis of alternative tillage and crop establishment practices for economically and environmentally efficient rice production. Sci. Rep. 2017, 7, 9342. [CrossRef] [PubMed]

34. Reddy, K.R.; Khaleel, R.; Overcash, M.R. Behavior and transport of microbial pathogens and indicator organism in soils treated with organic wastes. J. Environ. Qual. 1981, 10, 255-266. [CrossRef] 
35. Mehdi, S.M.; Sarfraz, M.; Abbas, S.T.; Shabbir, G.; Akhtar, A. Integrated nutrient management for rice-wheat cropping system in a recently reclaimed soil. Soil Environ. 2011, 30, 36-44.

36. Chaudhary, S.; Dheri, G.S.; Brar, B.S. Long-term effects of NPK fertilizers and organic manures on carbon stabilization and management index under rice-wheat cropping system. Soil Tillage Res. 2017, 166, 59-66. [CrossRef]

37. Kharub, A.S.; Sharma, R.K.; Mongia, A.D.; Chhokar, R.S.; Tripathi, S.C.; Sharma, V.K. Effect of rice (Oryza sativa) straw removal, burning and incorporation on soil properties and crop productivity under rice-wheat (Triticum aestivum) system. Indian J. Agric. Sci. 2004, 74, 295-299.

38. Paikaray, R.K.; Mahapatra, B.S.; Sharma, G.L. Effect of organic and inorganic sources of nitrogen on productivity and soil fertility under rice (Oryza sativa)-wheat (Triticum aestivum) crop sequence. Indian J. Agric. Sci. 2002, 72, 445-448.

39. Ghuman, B.S.; Sur, H.S. Effect of manuring on soil properties and yield of rainfed wheat. J. Indian Soc. Soil Sci. 2006, 54, 6-11.

40. Bhattacharya, R.; Chandra, S.; Singh, R.D.; Kundu, S.; Srivastva, A.K.; Gupta, H.S. Long-term farmyard manure application effects on properties of a silty clay loam soil under irrigated wheat-soybean rotation. Soil Tillage Res. 2007, 94, 386-396. [CrossRef]

41. Oborn, I.; Edwards, A.C.; Witter, E.; Oenema, O.; Ivarsson, K.; Withers, P.J.A.; Nilsson, S.I.; Stinzing, A.R. Element balances as a tool for sustainable nutrient management: A critical appraisal of their merits and limitations within an agronomic and environmental context. Eur. J. Agron. 2003, 20, 211-225. [CrossRef]

42. Janssen, B.H.; de Willigen, P. Ideal and saturated soil fertility as bench marks in nutrient management. II. Interpretation of chemical soil tests in relation to ideal and saturated soil fertility. Agric. Ecosyst. Environ. 2006, 116, 147-155. [CrossRef]

43. Ladha, J.K.; Pathak, H.; Krupnik, T.J.; Six, J.; Kessel, C.V. Efficiency of fertilizer nitrogen in cereal production: Retrospect and prospects. Adv. Agron. 2005, 87, 85-156.

44. Ghosh, B.N.; Singh, R.J.; Mishra, P.K. Soil and input management options for increasing nutrient use efficiency. In Nutrient Use Efficiency: From Basics to Advances; Rakshit, A., Ed.; Springer: New Delhi, India, 2015.

45. Abrol, I.P.; Gill, M.S. Regional office for Asia and Pacific (FAO) Publication; FAO: Roma, Italy, 1994; Volume 11, pp. 172-183.

46. Modgal, S.C.; Singh, Y.; Gupta, P.C. Nutrient management in rice-wheat cropping system. Fert. News 1995, 40, 49-54.

47. Patro, H.; Dash, D.; Parida, D.; Panda, P.K.; Kumar, A.; Tiwari, R.C.; Shahid, M. Effect of organic and inorganic sources of nitrogen on yield attributes, grain yield and straw yield of rice (Oryza sativa). Int. J. Pharma Biol. Sci. 2011, 2, 1-8.

48. Acharya, D.; Mandal, S.S. Effect of integrated nutrient management on the growth, productivity and quality of crops in rice (Oryza sativa L.) —Cabbage (Brassica oleracea)—Greengram (Vigna radiata) cropping system. Ind. J. Agron. 2010, 55, 1-5.

49. Brahmachari, K.; Choudhury, S.R.; Karmakar, S.; Dutta, S.; Ghosh, P. Sustainable nutrient management in rice (Oryza sativa) - Paira chickling pea (Lathyrus sativus)—Green gram (Vigna radiata) sequence to improve total productivity of land under coastal zone of West Bengal. Rajshahi Univ. J. Environ. Sci. 2011, 1, 51-61.

50. Yadav, G.S.; Datta, M.; Basu, S.; Debnath, C.; Sarkar, P.K. Growth and productivity of lowland rice (Oryza sativa) as influenced by substitution of nitrogenous fertilizer by organic sources. Indian J. Agric. Sci. 2013, 83, 1038-1042.

51. Jaga, P.K. Effect of integrated nutrient management on wheat-A review. Innovare J. Agric. Sci. 2013, 1, 185-191.

52. Aulakh, M.S.; Adhya, T.K. Impact of agricultural activities on emission of greenhouse gases-Indian perspective. In Proceedings of the International Conference on Soil, Water and Environmental Quality-Issues and Strategies; Indian Society of Soil Science: New Delhi, India, 2005; pp. 319-335.

53. Aulakh, M.S.; Khurana, M.P.S.; Singh, D. Water pollution related to agricultural, industrial and urban activities, and its effects on food chain: Case studies from Punjab. J. New Seeds 2009, 10, 112-137. [CrossRef]

54. Prasad, B.; Prasad, J.; Prasad, R. Nutrient management for sustainable rice and wheat production in calcareous soil amended with green manures, organic manures and zinc. Fert. News. 1995, 40, 39-45. 
55. Aulakh, M.S. Integrated nutrient management for sustainable crop production, improving crop quality and soil health, and minimizing environmental pollution. In Proceedings of the 19th World Congress of Soil Science, Soil Solutions for a Changing World, Brisbane, Australia, 1-6 August 2010.

56. Kundu, S.; Bhattacharyya, R.; Prakash, V.; Ghosh, B.N.; Gupta, H.S. Carbon sequestration and relationship between carbon addition and storage under rainfed soybean-wheat rotation in a sandy loam soil of the Indian Himalayas. Soil Tillage Res. 2007, 92, 87-95. [CrossRef]

57. Chander, K.; Goyal, S.; Mundra, M.C.; Kapoor, K.K. Organic matter, microbial biomass and enzyme activity of soils under different crop rotations in the tropics. Biol. Fert. Soils 1977, 24, 306-310. [CrossRef]

58. Wardle, D.A.; Yeates, G.W.; Nicholson, K.S.; Bonner, K.I.; Watson, R.N. Response of soil microbial biomass dynamics, activity and plant litter decomposition to agricultural intensification over a seven-year period. Soil Biol. Biochem. 1999, 31, 1707-1720. [CrossRef]

59. Schloter, M.; Dilly, O.; Munch, J.K. Indicators for evaluating soil quality. Agric. Ecosyst. Environ. 2003, 98, 255-262. [CrossRef]

60. Livia, B.; Uwe, L.; Frank, B. Microbial biomass, enzyme activities and microbial community structure in two European long-term field experiments. Agric. Ecosyst. Environ. 2005, 109, 141-152.

61. Kuttimani, R.; Somasundaram, E.; Velayudham, K. Effect of integrated nutrient management on soil microorganisms under irrigated banana. Int. J. Curr. Microbiol. Appl. Sci. 2017, 6, 2342-2350. [CrossRef]

62. Pernes-Debuyser, A.; Tessier, D. Soil physical properties affected by long-term fertilization. Eur. J. Soil Sci. 2004, 55, 505-512. [CrossRef]

63. Singh, G.; Singh, O.P.; Singh, S.; Prasad, K. Weed management in late sown wheat (Triticum aestivum) after rice (Oryza sativa) in rice-wheat system in rainfed lowland. Indian J. Agron. 2010, 55, 83-88.

64. Prasad, P.; Satyanarayana, V.; Murthy, V.; Boote, K.J. Maximizing yields in rice- groundnut cropping sequence through integrated nutrient management. Field Crop. Res. 2002, 75, 9-21. [CrossRef]

65. Parkinson, R. System based integrated nutrient management. Soil Use Manag. 2013, 29, 608. [CrossRef]

66. Zhang, F.; Cui, Z.; Chen, X.; Ju, X.; Shen, J.; Chen, Q.; Liu, X.; Zhang, W.; Mi, G.; Fan, M.; et al. Integrated nutrient management for food security and environmental quality in China. Adv. Agron. 2012, 116, 1-40.

67. Das, B.; Chakraborty, D.; Singh, V.; Aggarwal, P.; Singh, R.; Dwivedi, B.; Mishra, R. Effect of integrated nutrient management practice on soil aggregate properties, its stability and aggregate-associated carbon content in an intensive rice-wheat system. Soil Tillage Res. 2014, 136, 9-18. [CrossRef]

68. Khan, M.U.; Qasim, M.; Sarhad, I.U.K. Effect of integrated nutrient management on crop yields in rice-wheat cropping system. J. Agric. 2007, 23, 4. 